Pedagogik Jurnal Pendidikan, Maret 2014, Volume 9 Nomor 1, (1-8)

\title{
RELEVANSI MATA KULIAH EKONOMI MONETER DI UNIVERSITAS MUHAMMADIYAH PALANGKARAYA DENGAN KURIKULUM SMA BIDANG STUDI EKONOMI
}

\author{
Oleh : Iin Nurbudiyani *
}

\begin{abstract}
Abstrak
Penelitian ini bertujuan untuk mengetahuai sampai seberapa jauh kesesuaian antara mata kuliah Ekonomi Moneter di Universitas Muhammadiyah Palangkaraya dengan Kurikulum SMA Tahun yang meliputi materi, jumlah jam tatap muka yang tersedia. Dalam penelitian ini penulis menggunakan jenis penelitian penjajagan (exploratif) Sedangkan untuk mengumpulkan data yang diperlukan menggunakan metode dokumentasi dan metode interwiev. Subjek penelitian adalah Universitas Muhammadiyah Palangkaraya dan Guru Mata Pelajaran Ekonomi SMA Muhammadiyah I Kota Palangkaraya. Sedangkan objeknya adalah Silabus Mata Kuliah Ekonomi Moneter dan Guru Bidang Studi Ekonomi. Hasil penelitian menunjukkan: (1) Materi mata kuliah Ekonomi Moneter di FKIP Universitas Muhammadiyah Palangkaraya yang disampaikan 60\% telah sesuai dengan ketentuan Kurikulum SMA bidang studi Ekonomi. Kalau kita lihat kompetensi pada mata kuliah Ekonomi Moneter dengan 3 pokok bahasan terdapat 15 sub pokok bahasan. Sedangkan dalam kurikulum dengan 3 pokok bahasan terdapat 18 sub pokok bahasan pada kurikulumyang sama dengan sub pokok bahasan pada mata kuliah Ekonomi Moneter ada 9 sub pokok bahasan, (2) Jumlah jam tatap muka yang disediakan dalam silabus tidak sesuai dengan jumlah jam tatap muka pada ketentuan kurikulum, pada kurikulum terdapat 18 sub pokok bahasan dengan jumlah waktu 36 jam tatap muka. Sedangkan pada mata kuliah Ekonomi Moneter dengan 15 sub pokok bahasan dengan jumlah waktu 14 jam tatap muka.
\end{abstract}

Kata Kunci : $\quad$ Relevansi, mata kuliah ekonomi moneter, kurikulum SMA, bidang studi ekonomi

\section{PENDAHULUAN}

Pendidikan adalah proses pembebasan manusia dari kebodohan, kemiskinan dan kekufuran, dengan memperkuat kesadaran atas moralnya untuk memimpin kehidupan di dunia, menciptakan kemakmuran bersama. Pendidikan sebagai proses pengembangan manusia secara makro meliputi proses-proses pembudayaan, yaitu proses transformasi nilai-nilai budaya yang menyangkut nilai-nilai etis, estetis, dan budaya serta wawasan kebangsaan. Proses perubahan ini sudah dimulai sejak tahun 1968, kegiatan-kegiatan secara nasional, usaha-usaha penyertaan buku-buku pelajaran, media pembelajaran, saranaprasaran, teknologi, proyek-proyek pembangunan sarana fisik dan berbagai usaha lainnya yang telah mempengaruhi arah kebijakan dan pembinaan pendidikan secara nasional. Hal ini sejalan dengan tuntutan masyarakat yang selalu berubah.

Arah dan tujuan pendidikan yang digariskan dalam Garis-garis Besar Haluan Negara yang diputuskan pada tahun 1973, mencerminkan betapa masyarakat dan Negara Indonesia telah secara jelas menggariskan harapannya kepada dunia pendidikan. Oleh karena itu pemerintah menyadari betapa kita harus meninjau dan memperbaiki Kurikulum yang sudah berjalan itu agar sesuai dengan perkembangan dan tuntutan baru masyarakat dan bangsa Indonesia. Kebijkan

\footnotetext{
* Dr. Iin Nurbudiyani, M.Pd Dosen FKIP Universitas Muhammadiyah Palangkaraya
} 
tersebut telah melahirkan serangkaian kegiatan untuk menelaah dan mengembangkan Kurikulum baru yang lebih sesuai dengan tuntutan baru. Hasil kegiatan-kegiatan tersebut yang secara bersama telah dilakukan oleh bagian Penelitian dan Pengembangan Pendidikan dari Direktorat Jenderal Pendidikan Dasar dan Menengah, telah menjelma menjadi Kurikulum 1984, 2004, 2006 dan bahkan 2013 satu tahun yang lalu.

Sesuai dengan tuntutan Kurikulum tersebut diperlukan tenaga-tenaga pengajar yang siap pakai, yaitu lulusan Fakultas Keguruan dan Ilmu Pendidikan dari Universitas Muhammadiyah Palangkaraya. Untuk ini kami mengkhususkan penelitian pengajaran di Fakultas Keguruan dan Ilmu Pendidikan dari Universitas Muhammadiyah Palangkaraya Program Studi Pendidikan Ekonomi, dengan mengambil mata kuliah Ekonomi Moneter yang ada kaitannya dengan Kurikulum SMA Bidang Studi Ekonomi.

\section{KAJIAN PUSTAKA}

1. Kurikulum

\section{a. Pengertian Kurikulum}

Menurut J Galen Saylor dan William M Alexander, kurikulum meliputi segala pengalaman yang disajikan oleh sekolah agar anak mencapai tujuan yang telah ditentukan oleh guru. Menurut pengertian Webster's New Internasional Dictionary, kurikulum adalah pengaturan sebagai sejumlah mata pelajaran tertentu yang harus ditempuh atau sejumlah pengetahuan yang harus dikuasai untuk mencapai suatu tingkat atau ijazah. Sedangkan pengertian kurikulum menurut konsep baru dalam pendidikan modern, adalah bahwa kurikulum sebagai: (1) Segala pengalaman yang dihayati anak atas pimpinan sekolah termasuk kurikulum, (2) Kurikulum tidak terbatas pada pengalaman anak diantara keempat dinding kelas/pelajaran-pelajaran yang diberikan salama jam sekolah, (3) Kurikulum meliputi segala sesuatu yang dapat dimasukkan ke dalam lingkungan tanggung jawab sekolah, termasuk disini aktivitas ekstra kurikuler. Jika ditinjau dari tujuan pendidikan nasional Indonesia, kurikulum adalah kesatuan kegiatan yang terorganisir dan terintregasi dan dilakukan dalam hubungan dengan pendidikna dan terarah kepada tercapainya pendidikan nasional.

\section{b. Peran dan Fungsi Kurikulum}

Perubahan sebuah kurikulum sering hanya terfokus pada pengubahan dokumen saja, tetapi pelaksanaan pembelajaran, penciptaan suasana belajar, cara evaliasi atau asesmen pembelajaran, sering tidak berubah. Sehingga dapat dikatakan perubahan kurikulum hanya pada tataran konsep atau mengubah dokumen saja. Ini bisa dilihat dalam system pendidikan yang lama dimana kurikulum diletakkan sebagai aspek input saja. Dalam Dirjen Diknas tahun 2008, kurikulum bisa berperan sebagai: (1) Kebijakan manajemen pendidikan untuk menentukan arah pendidikannya, (2) Filosofi yang akan mewarnai terbentuknya masyarakat dan iklim akademik, (3) Pola Pembelajaran, (4) Atmosfir atau iklim yang terbentuk dari hasil interaksi manajerial sekolah dalam mencapai tujuan pembelajaran, (5) Rujukan kualitas dari proses penjaminan mutu, dan (6) Ukuran keberhasilan sekolah dalam menghasilkan lulusan yang bermanfaat bagi masyarakat. Dengan uraian di atas nampak bahwa 
kurikulum tidak hanya berarti sebagai suatu dokumen saja, namun mempunyai peran yang kompleks dalam proses pendidikan. Selanjutnya menurut Mc. Neil, J.D. (1990: 107) isi kurikulum memiliki empat fungsi yaitu: (1) Fungsi pendidikan umum, (2) Suplementasi, (3) Eksplorasi, (4) Keahlian. Bagi guru kurikulum berfungsi sebagai pedoman dalam pelaksanaan proses pembelajaran. Bagi kepala sekolah kurikulum berfungsi untuk menyusun perencanaan dan program sekolah. Bagi pengawas kurikulum akan berfungsi sebagai panduan dan melaksanakan supervisi, sedangkan bagi siswa kurikulum sebagai pedoman belajar.

\section{c. Pengembangan Kurikulum}

Pengembangan kurikulum merupakan suatu hal yang dapat terjadi kapan saja sesuai kebutuhan (Oemar Hamalik, 2007: 90). Perencanaan kurikulum adalah langkah awal membangun kurikulum ketika pembuat kurikulum mengambil keputusan dan tindakan untuk menghasilkan perencanaan yang akan digunakan oleh guru dan peserta didik. Penerapan kurikulum atau biasa disebut juga implementasi kurikulum berusaha menstransfer perencanaan kurikulum ke dalam tindakan operasional. Evaluasi kurikulum merupakan tahap akhir dari pengembangan kurikulum untuk menentukan seberapa besar hasil-hasil pembelajaran, tingkat ketercapaian program-program yang telah direncanakan, dan hasil-hasil kurikulum itu sendiri.

Prinsip-prinsip yang akan digunakan dalam kegiatan pengembangan kurikulum pada dasarnya merupakan kaidah-kaidah yang akan menjiwai suatu kurikulum. Oleh karena itu dalam implementasi kurikulum disuatu lembaga pendidikan sangat mungkin terjadi penggunaan prinsip-prinsip yang berbeda dengan kurikulum yang digunakan di lembaga pendidikan lainnya, sehingga akan ditemukan banyak sekali prinsip-prinsip yang digunakan dalam suatu pengembangan kurikulum. Dalam hal ini Nana Syaodih Sukmadinata (2009: 150) mengetengahkan prinsip-prinsip pengembangan kurikulum yang dibagi ke dalam dua kelompok, yaitu: (1) Prinsip-prinsip umum: relevansi, fleksibilitas, kontinuitas, praktis dan efektif, (2) Prinsip-prinsip khusus: prinsip berkenaan dengan tujuan pendidikan, prinsip berkenaan dengan pemilihan isi pendidikan, prinsip berkenaan dengan pemilihan proses belajar mengajar, prinsip berkenaan dengan pemilihan media dan alat pelajaran, dan prinsip berkenaan dengan pemilihan kegiatan penilaian.

Pemenuhan prinsip-prinsip di atas itulah yang membedakan antara penerapan satu Kurikulum Tingkat Satuan Pendidikan dengan kurikulum sebelumnya. Karena prinsip-prinsip itu boleh dikatakan sebagai ruh atau jiwanya kurikulum. Dalam menyikapi suatu perubahan kurikulum, banyak orang lebih terfokus hanya pada pemenuhan struktur kurikulum sebagai jasad dari kurikulum. Padahal jauh lebih penting adalah perubahan cultural (perilaku) guna memenuhi prinsip-prinsip khusus yang terkandung dalam pengembangan kurikulum.

\section{d. Kurikulum Tingkat Satuan Pendidikan \\ Kurikulum Tingkat Satuan Pendidikan (KTSP) merupakan kurikulum yang dikembangkan sesuai}


dengan satuan pendidikan, potensi sekolah, daerah, karakteristik sekolah atau daerah, sosial budaya masyarakat setempat, karakteristik peserta didik (Mulyasa, 2005: 8). KTSP merupakan pengembangan KBK yang bercirikan: (1) Orientasi pencapaian hasil dan dampak, (2) Berbasis standar kompetensi dan kompetensi dasar yang tertuang, (3) Pada standar isi, (4) Bertolak dari standar kompetensi lulusan, (5) Memperhatikan pengembangan kurikulum berdiversifikasi, Mengembangkan kompetensi secara utuh dan menyeluruh, (7) Menerpkan prinsip ketuntasan belajar. Dari uraian di atas dapat ditarik kesimpulan bahwa kurikulum operasional yang disusun dan dilaksanakan oleh masing-masing satuan pendidikan yang merefleksikan pengetahuan, keterampilan dan sikap sehingga dapat meningkatkan potensisiswa secara utuh.

\section{e. Relevansi Kurikulum}

Kata relevansi berasal dari bahasa inggeris relevant yang artinya bersangkutpaut. Sperber \& Wilson, D. (2009: 183), mendefinisikan relevansi dalam dua hal yaitu pertama relevansi merupakan masalah derajad dan kami tidak menyatakan apa pun tentang bagaimana cara menentukan derajad relevansi, kedua relevansi sebagai suatu hubungan antara asumsi dan konteks. Berangkat dari itu pengertian kurikulum dalam dunia pendidikan terus mengalami perkembangan sesuai dengan perkembangan jaman sehingga bukan hanya menyangkut sederetan amata pelajaran melainkan menyangkut sebagian besar aktivitas dalam pendidikan. Perkembangan tersebut melahirkan pendapat-pendapat para ahli dalam mendefinisikan kurikulum dari setiap sudut pandang mereka terhadap pendidikan. Sawyer, D.B. (2004: 41) menyatakan "The first is the view of curriculum as a written plan of action, which is reflected incurriculum documents that contain clearly stated learning objectives". Yang artinya kurikulum merupakan rencana tertulis dari kegiatan yang merupakan refleksi dari dokumen kurikulum yang berisi tujuan pembelajaran yang dinyatakan secara jelas.

Melihat ke dua definisi di atas maka kurikulum merupakan segala bentuk aktivitas atau kegiatan adala dunia pendidikan yang dapat mempengaruhi peserta didik selama berada dalam lingkungan sekolah serta hal-hal yang memiliki fungsi untuk mengantarkan pendidikan pada tujuannya. Namun secara khusus kurikulum disini merupakan serentetan rencana pengajaran atau materi yang disusun dalam suatu mata pelajaran tertentu yang tentunya setiap pengadaan dari bahan atau materi pelajaran tersebut menggunakan pertimbanganpertimbangan matang tentang tujuan pengajarannya. Berangkat dari definisi relevansi dan kurikulum, maka relevansi kurikulum adalah keterkaitan atau segala sesuatu yang memiliki hubungan dengan segala bentuk aktivitas atau kegiatan yang ada dalam dunia pendidikan yang dapat mempengaruhi peserta didik serta dapat mewujudkan tujuan pendidikan.

\section{PEMBAHASAN}

Data yang akan dianalisis adalah materi mata kuliah Ekonomi Moneter dengan Kurikulum SMA bidang studi Ekonomi, yang menyangkut materi yang ada pada mata kuliah Ekonomi Moneter dan juga ada dalam Kurikulum SMA bidang studi 
Ekonomi, dengan jam tatap muka yang kuliah Ekonomi Moneter. Dalam telah disediakan. Adapun cara penganalisaan itu dapat diambil kesimpulan penganalisaannya adalah dengan cara perbedaannya dan kesesuaiannya. Untuk membandingkan antara materi yang ada mengetahui adanya perbedaan dan dalam Kurikulum SMA bidang studi kesesuaian sebagai ilustrasi di bawah ini Ekonomi dengan yang ada juga dalam mata digunakan daftar klasifikasi sebagai berikut

\begin{tabular}{|ccc|l|}
\hline \multicolumn{3}{|c|}{ Prosentase } & Klasifikasi \\
\hline 80 & s/d & 100 & Sangat Sesuai \\
60 & s/d & 79 & Sesuai \\
40 & s/d & 59 & Cukup Sesuai \\
20 & s/d & 39 & Kurang Sesuai \\
00 & s/d & 29 & Tidak Sesuai \\
\hline
\end{tabular}

Tabel. 1

Silabus Mata Kuliah Ekonomi Moneter

\begin{tabular}{|c|c|l|c|}
\hline No & Pokok Bahasan & \multicolumn{1}{|c|}{ Uraian } & Alokasi Waktu \\
\hline 1 & Uang & 1.1 Pengertian uang & 2 minggu \\
& & 1.2 Sejarah uang & \\
& & 1.3 Jenis uang & \\
\hline 2 & Kredit & 2.4 Fungsi dan peranan uang & \\
& & 2.2 Fungsi kredit & \\
& & 2.3 Jenis kredit & \\
& & 2.4 Sumber kredit & \\
& & 2.5 Manfaat kredit & 3 minggu \\
& & 3.1 Sejarah Bank & \\
& Bank & 3.2 Fungsi Bank & \\
& & 3.3 Tugas Bank & \\
& & 3.4 Manajemen perbankan & \\
& & 3.5 Tata perbankan & \\
& & 3.6 Policy perbankan & \\
\hline
\end{tabular}

Apabila kita baca tabel.1 di atas, terdapat 15 sub pokok bahasan yang harus disampaikan dengan alokasi waktu 7 minggu atau 14 jam.

Tabel.2

Kurikulum Mata Pelajaran Ekonomi SMA

\begin{tabular}{|c|c|c|c|}
\hline No & Pokok Bahasan & \multicolumn{1}{|c|}{ Uraian } & Alokasi Waktu \\
\hline 1 & Uang & - Pertumbuhan uang mempunyai & 15 jam \\
& & sejarah yang panjang hingga & \\
& & munculnya uang logam, kertas dan & \\
& & GIR & \\
& & Uang mempunyai beberapa fungsi & \\
\hline
\end{tabular}




\begin{tabular}{|c|c|c|c|}
\hline & & $\begin{array}{l}\text { - } \begin{array}{l}\text { Atas dasar berbagai pandangan } \\
\text { timbul berbagai teori nilai uang } \\
\text { - }\end{array} \text { Terdapat hubungan antara jumlah } \\
\text { barang yang dibeli dan jumlah uang } \\
\text { yang dibayarkan, sehingga timbul } \\
\text { pengertian daya beli uang } \\
\text { - } \\
\text { Perbedaan pandangan menimbu- } \\
\text { lkan berbagai teori daya beli uang } \\
\text { - } \quad \text { Uang memiliki berbagai macam } \\
\text { standar } \\
\text { - } \quad \text { Terdapat hubungan antara uang dan } \\
\text { kehidupan ekonomi nasional } \\
\text { sehingga muncul pengertian inflasi, } \\
\text { deflasi dikaitkan dengan taraf } \\
\text { kemakmuran bangsa }\end{array}$ & \\
\hline 2 & Kredit & $\begin{array}{ll}\text { - } & \text { Timbulnya kredit memerlukann } \\
& \text { persyaratan tertentu } \\
\text { - } & \text { Kredit mempunyai fungsi tertentu } \\
\text { - } & \text { Lembaga dan bunga kredit diatur } \\
\text { oleh peraturan tertentu } \\
\text { - } \\
\text { Penciptaan kredit melalui proses } \\
\text { tertentu }\end{array}$ & 9 jam \\
\hline 3 & Bank & 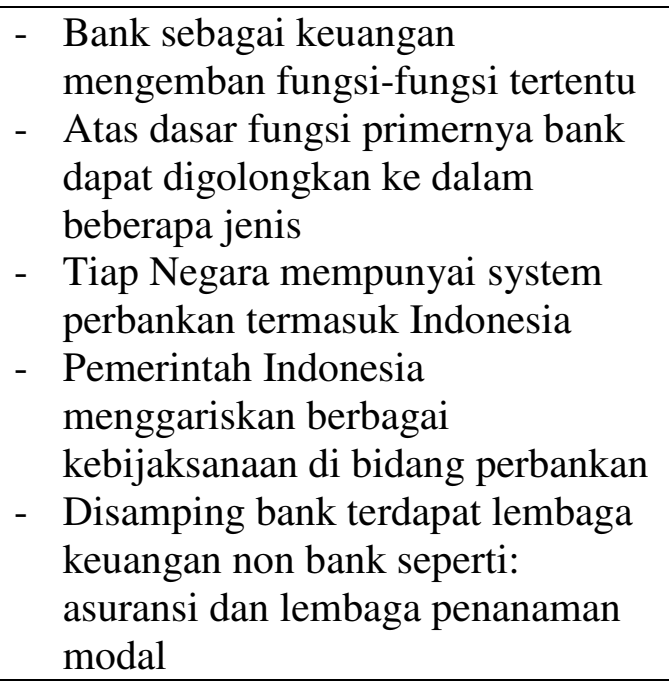 & 12 jam \\
\hline
\end{tabular}

Apabila kita baca tabel. 2 di atas, dapat kita sebutkan waktu yang digunakan adalah 36 jam pelajaran/tatap muka dengan 16 sub pokok bahasan. Untuk mengadakan penganalisaan maka tabel. 1 kita bandingkan dengan tabel. 2, bila kita lihat dan kita amati maka kita akan melihat kekurangan dan kelebihan pada silabus maupun pada kurikulum sebagai berikut:

1. Materi pengajaran

Untuk bahan pengajaran ini ditinjau dari isi materi pelajaran yang disampaikan walaupun judul materi pelajaran tersebut berbeda, terdapat kesamaan atau 
kesesuaian 9 sub pokok bahasan (60\%), dan terdapat kelebihan 6 pokok sub pokok bahasan (40\%). Dari analisa ini menunjukkan bahwa materi mata kuliah Ekonomi Moneter di Universitas Muhammadiyah Palangkaraya lebih banyak dari pada Kurikulum SMA bidang studi Ekonomi, hal ini wajar dengan pertimbangan: (a) Kelompok yang menerima materi berbeda yaitu mahasiswa dengan siswa. Mahasiswa akan lebih mudah menerima karena pengetahuan, penalaran dan cara belajar mahasiswa lebih luas, lebih dalam dan lebih teratur, (b) Pengajaran pada tingkat siswa sebagai dasar, sedangkan pada mahasiswa selain sebagai dasar juga perlu sebagai pengayaan, (c) Mahasiswa lulusan Universitas Muhammadiyah Palangkaraya diharapkan jadi pengajar pada tingkat SMA. Terdapat kekurangan sebesar 3 sub pokok bahasan, dari analisa ini menunjukkan bahwa ada beberapa materi mata kuliah Ekonomi Moneter yang dalam silabus tidak ada, sedangkan dalam kurikulum ada, hal ini dikarenakan: (a) Materi yang tidak ada dalam silabus tersebut diberikan pada mata kuliah lain yang ada di jurusan Pendidikan Ekonomi, (b) Materi yang tidak ada dalam silabus tersebut merupakan bagian dari sub pokok bahasan, sedangkan dalam kurikulum termasuk dalam sub pokok bahasan, (c) Materi yang ada dalam silabus Ekonomi Moneter tidak diuraikan secara mendetail, sedangkan dalam kurikulum lebih terperinci

2. Alokasi waktu

Bila dilihat dalam tabel. 1, tentang silabus yang terdiri 15 sub pokok bahasan yang harus disampaikan selama 14 jam tatap muka, dimana dari 14 jam tatap muka tersebut terbagi-bagi untuk tiap sub pokok bahasan yang masingmasing sub pokok bahasan tersebut tidak tentu sama alokasi waktu pembahasannya. Kemudian pada tabel. 2 , yaitu data kurikulum yang terdiri dari 18 sub pokok bahasan yang disampaikan dalam 36 jam tatap muka yang masingmasing sub pokok bahasan tersebut tidak tentu sama alokasi waktu pembahasannya. Jika kita bandingkan dan kita amati antara tabel. 1 denga tabel. 2, jumlah jam tatap muka pada silabus 2 kali lebih sedikit dari pada jumlah jam tatap muka pada kurikulum. Untuk menyeimbangkan terjadinya pengurangan waktu dapat digunakan: (a) Sistem CBSA, yaitu cara belajar siswa aktif, (b) Mata kuliah yang bersifat pengayaan dapat disampaikan dalam bentuk tugas-tugas, (c) Materi dalam kuliah butir-butirnya saja, tidak seperti dalam pengajaran pada SMA.

\section{KESIMPULAN}

Dari analisa data tersebut di atas dapat diambil kesimpulan sebagai berikut:

1. Materi mata kuliah Ekonomi Moneter di FKIP Universitas Muhammadiyah Palangkaraya yang disampaikan $60 \%$ telah sesuai dengan ketentuan Kurikulum SMA bidang studi Ekonomi. Kalau kita lihat kompetensi pada mata kuliah Ekonomi Moneter dengan 3 pokok bahasan terdapat 15 sub pokok bahasan. Sedangkan dalam kurikulum dengan 3 pokok bahasan terdapat 18 sub pokok bahasan pada kurikulumyang sama dengan sub pokok bahasan pada mata kuliah Ekonomi Moneter ada 9 sub pokok bahasan, bila kita jadikan prosen ada $60 \%$. Prosentase ini kalau kita masukkan dalam daftar klasifikasi menunjukkan bahwa materi mata kuliah Ekonomi Moneter di Universitas 
Pedagogik Jurnal Pendidikan, Maret 2014, Volume 9 Nomor 1, ( $1-8$ )

Muhammadiyah sesuai dengan kurikulum, pada kurikulum terdapat 18 Kurikulum SMA bidang studi Ekonomi. sub pokok bahasan dengan jumlah waktu Kesembilan sub pokok bahasan yang sesuai itu adalah: (a) Sejarah uang, (b) Pengertian uang, (c) Jenis-jenis uang, (d) Fungsi dan peran uang, (e) Fungsi kredit, (f) Fungsi Bank, (g) Managemen Bank, (h) Tata perbankan, (i) Policy perbankan.

2. Jumlah jam tatap muka yang disediakan dalam silabus tidak sesuai dengan jumlah jam tatap muka pada ketentuan 36 jam tatap muka. Sedangkan pada mata kuliah Ekonomi Moneter dengan 15 sub pokok bahasan dengan jumlah waktu 14 jam tatap muka. Sehingga jumlah jam tatap muka pada mata kuliah Ekonomi Moneter akan dua kali lebih sedikit dari jumlah jam tatap muka pada Kurikulum SMA

\section{DAFTAR PUSTAKA}

Abu Ahmadi. (1984). Pengantar kurikulum. Jakarta: PT. Bina Ilmu

Baker, W. James. (1992). Bagaimana mengajar secara sistematis. Yogjakarta: Yayasan Kanisius.

Baker, W. James. (1992). Bagaimana merencanakan suatu program pengajaran. Yogjakarta: Yayasan Kanisius.

Mc. Neil, J.D. (1990). Curriculum a comprehensive introduction. London: Library of congress cataloging in publicating data.

Mulyasa. (2002). Kurikulum berbasis kompetensi konsep karakteristik dan implementasi. Bandung: Remaja Rosdakarya.

Nasution, S. (1982). Asas-asas kurikulum. Bandung: Jemmats.

Rooijakers, AD. (1984). Mengajar dengan sukses. Jakarta: Gramedia.

Sawyer, D.B. (2004). Fundamental aspects of interpreter education. Amsterdam: Benjamins Publishing Company.

Sutrisno Hadi. (1996). Metodologi research I. Yogyakarta: Andi Ofset 